\title{
Chilli thrips Scirtothrips dorsalis Hood (Insecta: Thysanoptera: Thripidae) 1
}

Vivek Kumar Jha, Dakshina R. Seal and Garima Kakkar²

\section{Introduction}

The chilli thrips, Scirtothrips dorsalis Hood, is an important pest of various vegetable, ornamental and fruit crops in southern and eastern Asia, Africa, and Oceania (Ananthakrishnan 1993, CABI/EPPO 1997, CAB 2003).

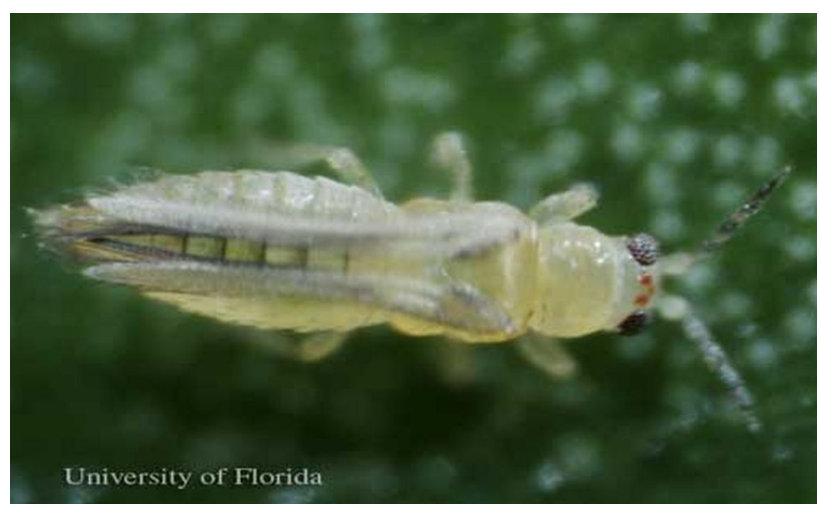

Figure 1. Dorsal view of adult chilli thrips, Scirtothrips dorsalis Hood. Credits: Vivek K Jha, University of Florida

Due to its diverse vegetation and subtropical climate, Florida is extremely suitable for the establishment of invasive alien flora and fauna
(Ferriter et al. 2006). In the United States, the chilli thrips, Scirtothrips dorsalis Hood, is a relatively new, introduced insect pest in Florida and Texas.

\section{Synonymy}

Anaphothrips andreae Karny 1925

Heliothrips minutissimus Bagnall 1919

Neophysopus fragariae Girault 1927

Scirtothrips andreae (Karny)

Scirtothrips fragariae (Girault)

Scirtothrips minutissimus (Bagnall)

Scirtothrips padmae Ramakrishna 1942

\section{Life Cycle and Biology}

The life cycle stages of $S$. dorsalis include egg, first and second instar larvae, prepupa, pupa and adult. Gravid females insert the eggs inside plant tissues above the soil surface. The eggs are

1. This document is EENY-463, one of the Featured Creatures series of the Entomology and Nematology Department, Cooperative Extension Service, Institute of Food and Agricultural Sciences, University of Florida. Published October 2009. Revised January 2010. This document is also available on Featured Creatures Web site at http://entomology.ifas.ufl.edu/creatures. Please visit the EDIS Web site at http://edis.ifas.ufl.edu. Additional information on these organisms, including many color photographs, is available at the Entomology and Nematology Department Web site at http://entnemdept.ifas.ufl.edu/.

2. Vivek Kumar Jha, Dakshina R. Seal and Garima Kakkar, Tropical Research and Education Center, Entomology and Nematology Department, Cooperative Extension Service, Institute of Food and Agricultural Sciences, University of Florida, Gainesville, FL.

The Institute of Food and Agricultural Sciences (IFAS) is an Equal Opportunity Institution authorized to provide research, educational information and other services only to individuals and institutions that function with non-discrimination with respect to race, creed, color, religion, age, disability, sex, sexual orientation, marital status, national origin, political opinions or affiliations. U.S. Department of Agriculture, Cooperative Extension Service, University of Florida, IFAS, Florida A. \& M. University Cooperative Extension Program, and Boards of County Commissioners Cooperating. Millie Ferrer-Chancy, Interim Dean 
microscopic ( $0.075 \mathrm{~mm}$ long and $0.070 \mathrm{~mm}$ wide), kidney-shaped and creamy white in color (Seal et al. 2009a). The eggs hatch between two to seven days, depending upon temperature. Larvae and adults tend to gather near the mid-vein or borders of the host leaf.

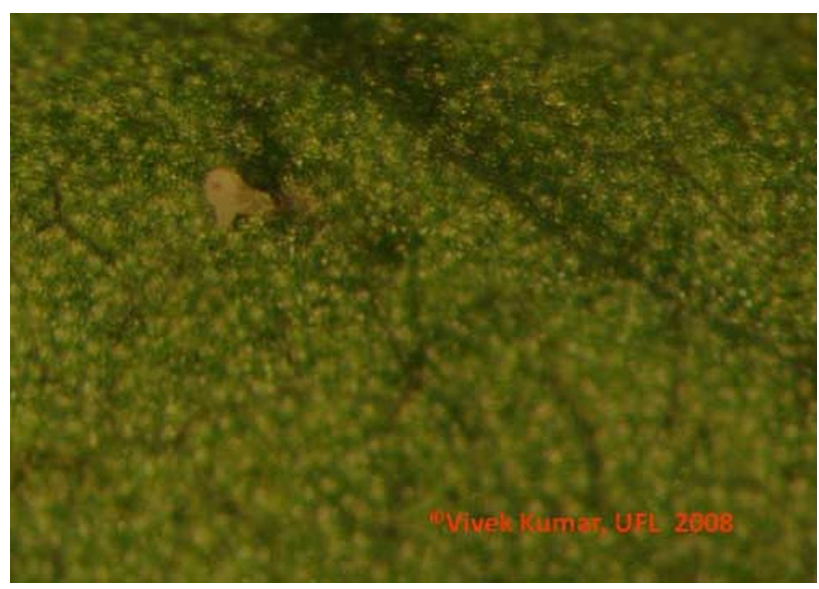

Figure 4. First instar larva of the chilli thrips, Scirtothrips dorsalis Hood, initiating its emergence from an egg on a cotton leaf. Credits: Vivek K Jha, University of Florida

Unlike other thrips, pupae of chilli thrips are generally found on leaves, leaf litter or on the axils of leaves, in curled leaves or under the calyces of flowers and fruits.

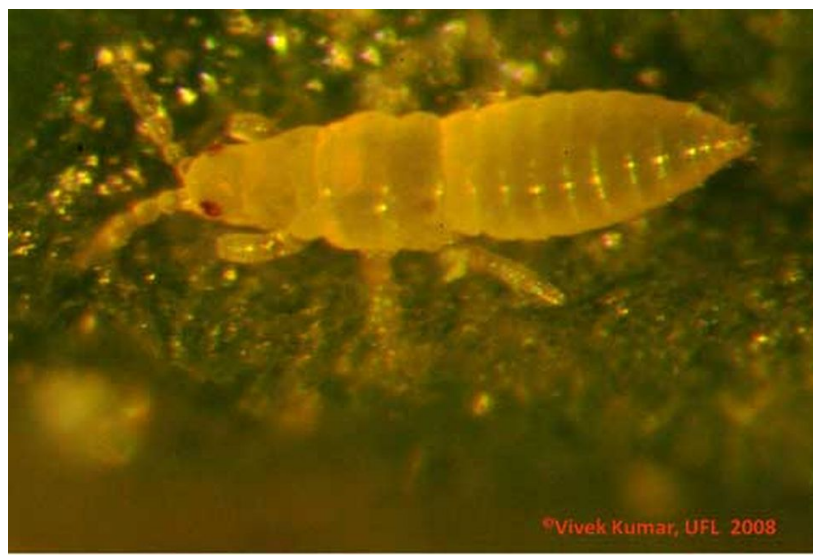

Figure 6. Larva of the chilli thrips, Scirtothrips dorsalis Hood, feeding on cotton leaf. Credits: Vivek K Jha, University of Florida

\section{Hosts}

Before its arrival in the Western Hemisphere, $S$. dorsalis was known to infest a wide variety of hosts plant belonging to more than 100 plant taxa among 40 families (Mound and Palmer 1981). After its introduction into the Western Hemisphere, $S$. dorsalis was found to attack additional taxa of plants (Klassen

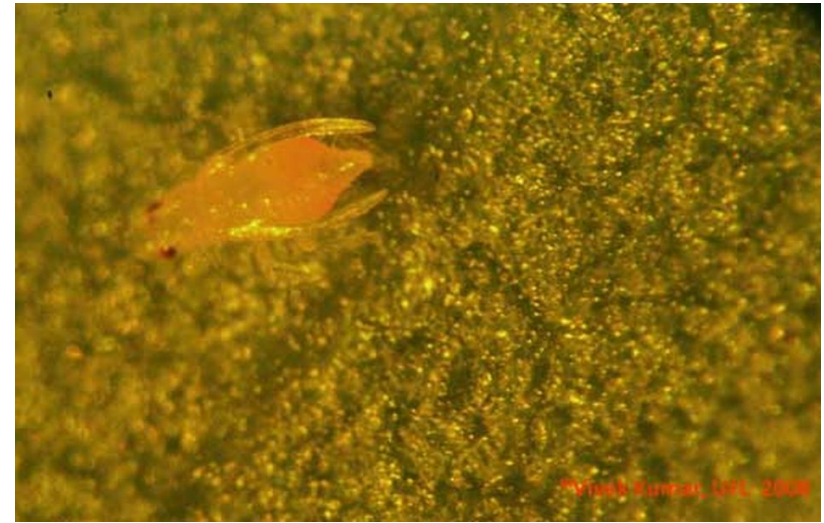

Figure 7. Pupa of chilli thrips, Scirtothrips dorsalis Hood, feeding on cotton leaf. Credits: Vivek K Jha, University of Florida

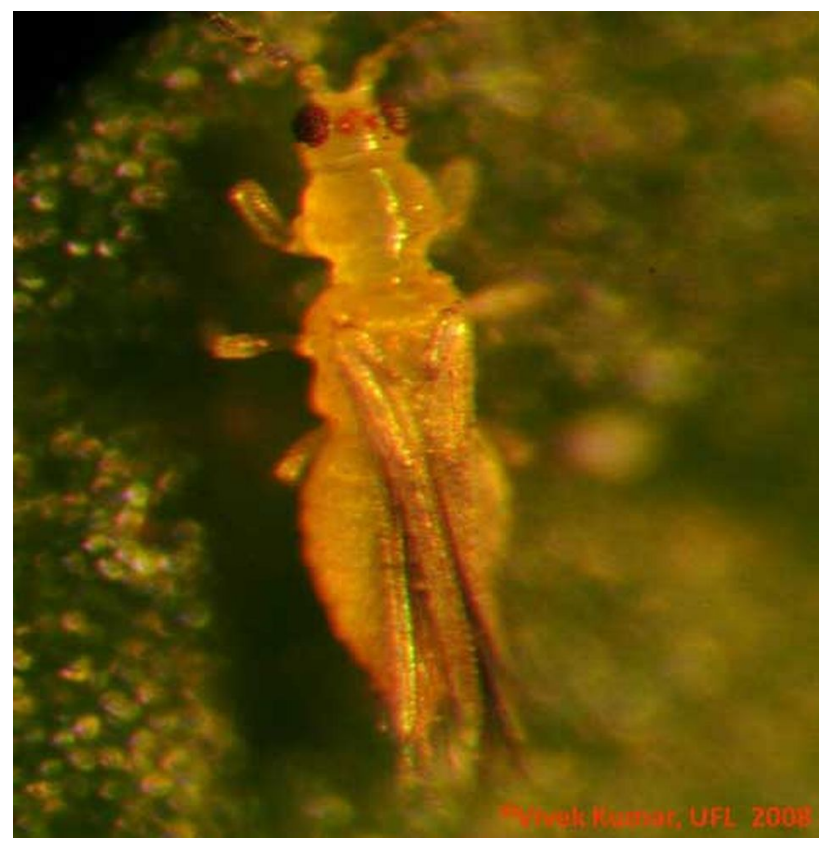

Figure 8. Adult chilli thrips, Scirtothrips dorsalis Hood, feeding on cotton leaf. Credits: Vivek K Jha, University of Florida

et al. 2008, Osborne 2008, Venette and Davis 2004). While their main wild host-plants belong to the pea family (Fabaceae), such as Acacia, Brownea, Mimosa and Saraca, the chilli thrips has also been recorded as a pest of numerous other economically important host plants in various plant families.

Among the potential economically important hosts of this pest in Western Hemisphere listed by Venette and Davis (2004) are banana, bean, cashew, castor, citrus, cocoa, corn, cotton, eggplant, grapes, litchi, longan, mango, melon, peanut, pepper, poplar, rose, strawberry, sweet potato, tea, tobacco, tomato, and wild yams (Dioscorea spp.). Scirtothrips dorsalis 


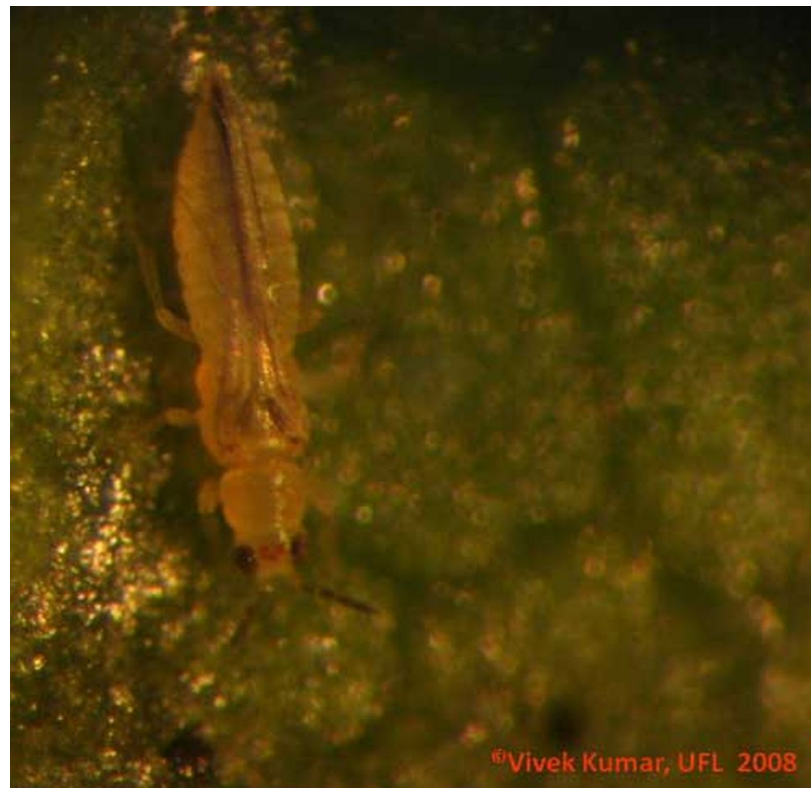

Figure 9. Adult chilli thrips, Scirtothrips dorsalis Hood, feeding on cotton leaf. Credits: Vivek K Jha, University of Florida

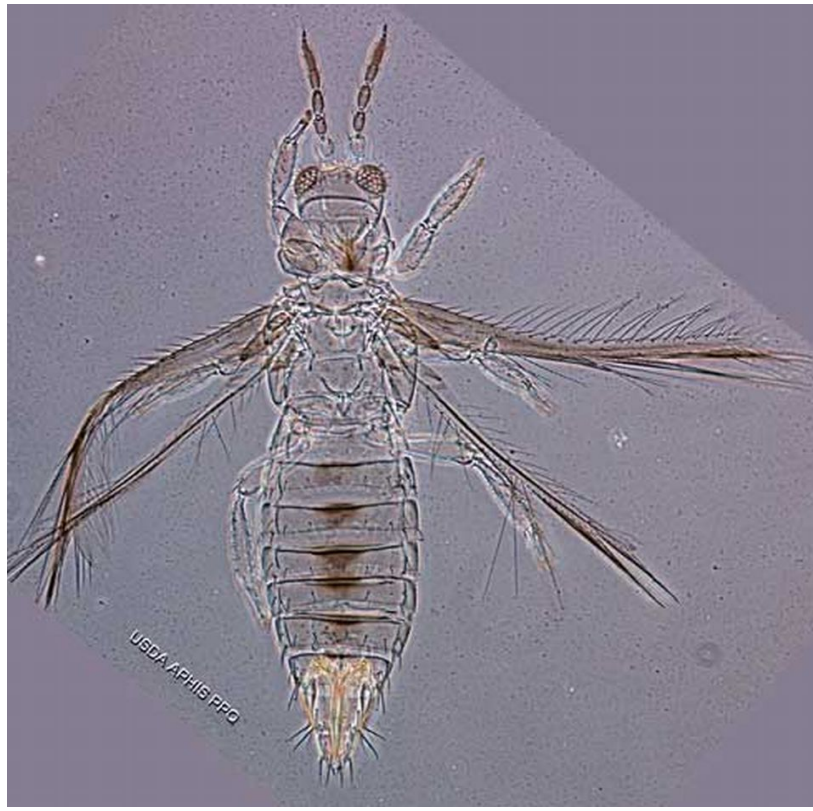

Figure 10. Adult chilli thrips, Scirtothrips dorsalis Hood. Credits: Thomas Skarlinsky, USDA-APHIS

is a significant pest of ornamental plantings in Florida.

\section{Plants in Florida on which S. dorsalis is known to reproduce are as follows:}

- Antirrhinum majus L. - Liberty Classic white snapdragon

- Arachis hypogaea L. - peanut or groundnut grown in greenhouse
- Begonia sp. - begonia

- Breynia nivosa (W. Bull) Small - snow bush, snow-on-the-mountain

- Capsicum annum L. - pepper

- Celosia argentea L. - celosia, red fox

- Coreopsis sp. - tickseed

- Cucumis sativus L. - cucumber

- Cuphea sp.- waxweed, tarweed

- Duranta erecta L. - golden dewdrop, pigeonberry, skyflower

- Euphorbia pulcherrima Willd. - poinsettia

- Eustoma grandiflorum (Raf.)Shinn. - Florida blue lisianthus

- Ficus elastica 'Burgundy' Roxb. ex Hornem Burgundy rubber tree

- Fragaria x ananassa - strawberry

- Gaura lindheimeri Engelm. \& Gray Lindheimer's beeblossom

- Gerbera jamesonii H. Bolus ex Hook. f. Gerber daisy

- Glandularia x hybrida (Grönland \& Rümpler) Neson \& Pruski - verbena

- Gossypium hirsutum L. - cotton grown in greenhouse

- Hedera helix L. - English ivy

- Impatiens walleriana Hook. f. - super elfin white

- Lagerstroemia indica L. - crape myrtle

- Ligustrum spp. - ligustrum

- Ocimum basilicum L. - sweet basil

- Pelargonium x hortorum Bailey - geranium

- Pentas lanceolata (Forssk.) Deflers - graffiti white 
- Petunia x hybrida - petunia easy wave red

- Pittosporum tobira (Thunb.) W. T. Aiton variegated pittosporum

- Plectranthus scutellarioides (L.) R. - coleus

- Plumbago auriculata Lam. - Cape leadwort, plumbago, jamin azul

- Ricinus communis L. - castor bean

- Rhaphiolepis umbellate (Thunb.) Makino Yeddo hawthorn

- Richardia brasiliensis Gomes - Brazil pusley, tropical Mexican clover, in greenhouse

- Rhododendron sp.

- Rosa sp. - rose

- Salvia farinacea Benth. - victoria blue

- Shefflera arbicola (Hayata) Merr. - umbrella tree

- Tagetes patula L. - marigold

- Tradescatia zebrina hort. ex Bosse - wandering jew

- Vaccinium corymbosum L. - highbush blueberry

- Viburnum odoratissimum var. awabuki (K. Koch) Zabel - sweet viburnum

- Viburnum suspensum Lindl. - viburnum

- Viola x wittrockiana Gams - Wittrock's violet

- Vitis vinifera L. - grapevine

- Zinnia elegans Jacq. - zinnia profusion white

(from Klassen et al. 2008, Osborne 2008)

\section{Host list of chilli thrips, Scirtothrips dorsalis among different families of plants}

Actinidiaceae: Actinidia deliciosa

Amaranthaceae: Alternanthera sessilis, Amaranthus spp.
Anacardiaceae: Anacardium occidentale, Mangifera indica

Asparagaceae: Asparagus officinalis

Asteraceae: Dahlia pinnata, Imorphotheca aurantiaca, Helianthus annuus

Caprifoliaceae: Viburnum awabuki

Chenopodiaceae: Beta vulgaris

Convolvulaceae: Ipomoea batatas

Cucurbitaceae: Citrullus lanatus, Cucumis melo, Cucumis sativus, Cucurbita pepo

Ebenaceae: Diospyros kaki

Euphorbiaceae: Hevea brasiliensis, Ricinus communis

Fabaceae: Acacia auriculiformis, Acacia brownie, Arachis hypogaea, Brownea spp., Dolichos lablab, Glycine max, Melilotus indica, Mimosa pudica, Phaseolus vulgaris, Saraca minor, Saraca spp., Tamarindus indica, Vigna radiate

Hydrangeaceae: Hydrangea spp.

Liliaceae: Allium cepa, Allium sativum

Lythraceae: Cuphea hyssopifolia

Malvaceae: Gossypium hirsutum

Moraceae: Morus sp.

Myrtaceae: Syzygium samarangense

Nelumbonaceae: Nelumbo lutea, Nelumbo nucifera

Passifloraceae: Passiflora edulis

Poaceae: Zea mays

Polygonaceae: Fagopyrum esculentum

Portulacaceae: Portulaca oleracea

Punicaceae: Punica granatum

Rhamnaceae: Zizyphus mauritiana 
Rosaceae: Fragaria chiloensis, Prunus persica, Pyrus spp., Rosa spp., Rubus spp.

Rutaceae: Citrus aurantiifolia, Citrus sinensis

Salicaceae: Populus deltoids

Sapindaceae: Dimocarpus longan, Litchi chinensis, Nephelium lappaceum

Solanaceae: Capsicum annuum, Capsicum frutescens, Lycopersicon esculentum, Nicotiana tabacum, Solanum melongena, Solanum nigrum

Theaceae: Camellia sinensis

Vitaceae: Vitis pteroclada, Vitis vinifera

(from Holtz 2006)

\section{Damage}

Thrips possesses piercing and sucking mouthparts and cause damage by extracting the contents of individual epidermal cells leading to necrosis of tissue. This changes the tissue color from silvery to brown or black. Chilli thrips create damaging feeding scars, distortions of leaves, and discolorations of buds, flowers and young fruits by feeding on the meristems of the host plant's terminals and on other tender parts above the soil surface. Scirtothrips dorsalis has not been reported feeding on mature host tissues. According to Sanap and Nawale (1987), adult and nymphs of $S$. dorsalis suck the cell sap of leaves, causing rolling of the leaf upward and leaf size reduction. For example, a heavy infestation of $S$. dorsalis in pepper plants changes the appearance of the plant to what is called "chilli leaf curl."

Appearance of discolored or disfigured plant parts suggests the presence of $S$. dorsalis.

A severe infestation of chilli thrips makes the tender leaves and buds brittle, resulting in complete defoliation and total crop loss. Infested fruits develop corky tissues (Seal et al. 2006b). Sometimes $S$.

dorsalis infested plants superficially appear like broad mite infested plant. On many hosts, after a heavy infestation chilli thrips also start feeding on the upper surface of leaves.

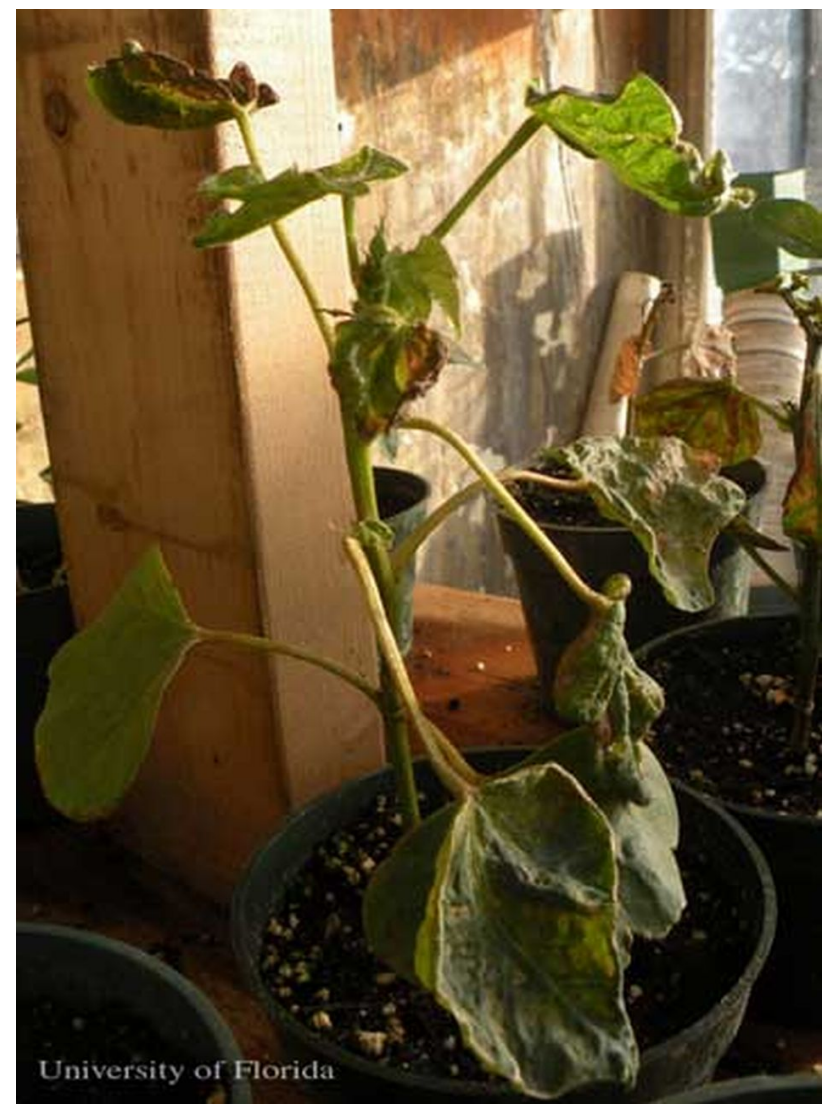

Figure 11. Cotton plant heavily infested with the chilli thrips, Scirtothrips dorsalis Hood. Credits: Vivek K Jha, University of Florida

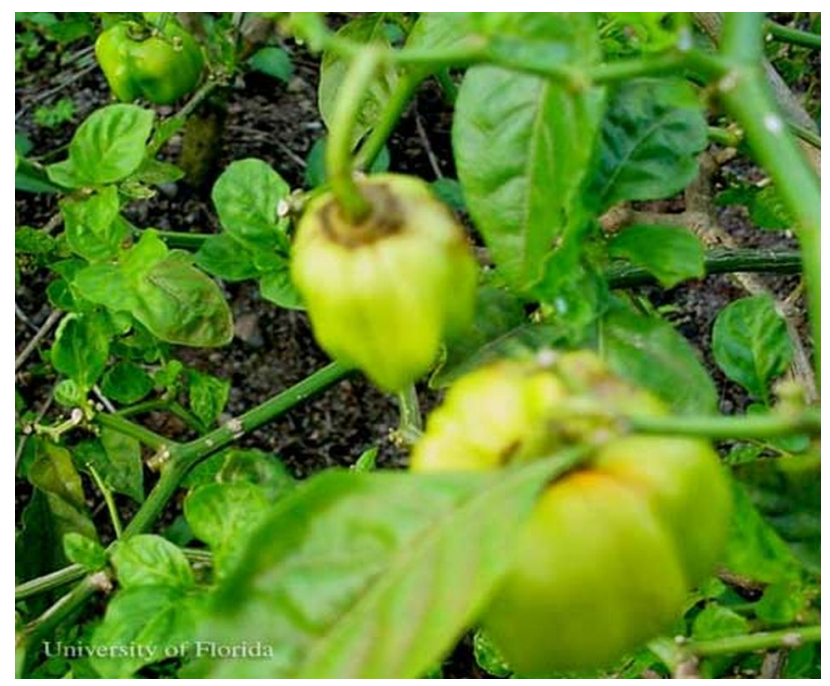

Figure 14. Feeding on host plant by the chilli thrips, Scirtothrips dorsalis Hood, also results in softening of calyx which causes premature falling of fruits. Credits: Vivek K Jha, University of Florida 


\section{Symptoms of Damage:}

- Silvering of the leaf surface

- Linear thickenings of the leaf lamina

- Brown frass markings on the leaves and fruits

- Grey to black markings on fruits often forming a conspicuous ring of scarred tissue around the apex

- Fruit distortion and early senescence of leaves

\section{Disease Transmission}

Scirtothrips dorsalis also posseses strong viruliferous behavior for seven recorded viruses. This species transmits chilli leaf curl (CLC) virus, and peanut necrosis virus (PBNV) (Mound and Palmer 1981, Ananthakrishnan 1993). In 2003, Rao et al. found chilli thrips as vectors of tobacco streak virus (TSV) in groundnut crops in India. Recently, in Thailand its role as a vector of three tospoviruses (i.e., melon yellow spot virus (MYSV), watermelon silver mottle virus (WsMoV), and capsicum chlorosis virus $(\mathrm{CaCV}))$ in field crops was confirmed (Chiemsombat et al. 2008).

\section{Management}

Development of effective management practices for $S$. dorsalis is still in its infancy. Many recommendations have been suggested by the World Vegetable Center (AVRDC) which could serve as basic management practices for this pest.

Management practices include crop rotation, removal of weeds (which may serve as hosts), and supporting the maximum use of natural enemies, including predators and parasites, and rotating insecticides.

Chemical control. Upon the establishment of $S$. dorsalis in the Caribbean in 2003 there was a paucity of information for effective management of this insect with modern insecticides. In order to impede the development of insecticide resistance it is always advisable to use insecticides from different classes in rotation. Pyrethroids have never been reported to provide effective control against $S$. dorsalis (Seal et al. 2006a). Various formulations of imidacloprid used as either soil drench or foliar application provide effective control of $\mathrm{S}$. dorsalis without harming natural control agents. Imidacloprid suppresses $S$. dorsalis populations for many days (Seal et al. 2009b). Spinetoram gives the best result when used as a foliar application and imidacloprid as soil drench (Seal et al. 2008). In addition, these two insecticides when applied as above allow the continuous growth and development of natural enemies of $S$. dorsalis.

While the above provides general guidelines, for recommended controls see the University of Florida Chili Thrips Web site.

Biological control. Various biological control agents, including minute pirate bugs, Orius spp. (Hemiptera: Anthocoridae) and entomopathogenic nematodes, Thripinema spp. (Tylenchida: Allantonematidae), have been reported to effectively control field populations of the chilli thrips. Adults of Orius insidiosus feed on all the life stages of thrips. Because Orius insidiosus also feeds on aphids, mites, moth eggs and pollen, its population does not decline strongly even if thrips populations are drastically reduced. Thripinema species are entomogenous nematodes which parasitize female thrips and make them incapable of laying eggs, leading to the reduction of thrips populations. In addition, they also reduce food consumption of these thrips, resulting in limited feeding damage.

Arthurs et al. (2009) evaluated two phytoseiid mites, Neoseiulus cucumeris and Amblyseius swirskii, as potential biological control agents of the chilli thrips and reported that Amblyseius swirskii can be a promising tool in managing chilli thrips on pepper. Other predators of chilli thrips which are being investigated, but on which adequate practical studies to assess their potential as significant natural enemies of thrips have not been done, include:

- lacewings, Chrysoperla spp.

- ladybird beetles

- predatory thrips, such as Franklinothrips vespiformis (vespiform thrips), Scolothrips sexmaculatus (sixspotted thrips), Selenothrips rubrocinctus (redbanded thrips), Leptothrips mali (black hunter thrips), 
- predatory phytoseiid mites, such as Amblyseius spp., Euseius hibisci and Euseius tularensis.

When used alone, the fungal pathogen Beauveria bassiana is not effective in controlling chilli thrips adults or larvae, but produced better result when used in combination with Tricon (an experimental product consisting of borax, orange oil and biodegradable surfactants) (Jha, unpublished data).

\section{Selected References}

Amin BW. 1979. Leaf fall disease of chilly and pepper in Maharashtra, India. Pans 25: 131-134.

Amin BW. 1980. Techniques for handling thrips as vectors of tomato spotted wilt virus and yellow spot virus of groundnut, Arachis hypogea $\mathrm{L}$. Occasional Paper. Groundnut Entomology ICRISAT, 80: 1-20.

Ananthakrishnan TN. 1993. Bionomics of thrips. Annual Review of Entomology 38: 71-92.

Arthurs S, McKenzie CL, Chen J, Dogramaci M, Brennan M, Houben K, Osborne L. 2009. Evaluation of Neoseiulus cucumeris and Amblyseius swirskii (Acari: Phytoseiidae) as biological control agents of chilli thrips, Scirtothrips dorsalis (Thysanoptera: Thripidae), on pepper. Biological Control 49: 91-96.

CABI/EPPO. 1997. Quarantine Pests for Europe, 2nd edition. CAB International, Wallingford, UK. $1440 \mathrm{pp}$.

CABI. 2003. Crop Protection Compendium: Global Module. CAB International, Wallingford, UK.

Chiemsombat P, Gajanandana O, Warin N, Hongprayoon R, Bhunchoth A, Pongsapich P. 2008. Biological and molecular characterization of tospoviruses in Thailand. Archives of Virology 153: 571-577.

Chang NT. 1995. Major pest thrips in Taiwan. pp 105-108. In Parker BL, Skinner M, Lewis T (editors), Thrips Biology and Management. Plenum Press, New York, NY.

EPPO. 2005. EPPO Standards - Diagnostic protocols for regulated pests - Scirtothrips aurantii,
Scirtothrips citri, Scirtothrips dorsalis. OEPP/EPPO Bulletin 35: 353-356.

Ferriter A, Doren B, Goodyear C, Thayer D, Bruch J, Toth L, Bondle M, Lane J, Schmitz D, Pratt P, Snow S, Langeland K. 2006. Chapter 9: The Status of Nonindigenous Species in the South Florida Environment. 2006 South Florida Environment Report. Department of Environmental Protection. Tallahassee, FL.

FNGA. 2003. The unlucky 13. Report of the Major Nursery Pest \& Disease Identification Task Force. Florida Nursery Growers and Landscape Association, Orlando, Florida, USA. 1 p.

Hodges G, Edwards GB, Dixon W. (October 2005). Chilli thrips, Scirtothrips dorsalis Hood (Thysanoptera: Thripidae): a new pest thrips for Florida. Florida Department of Agriculture \& Consumer Services, Division of Plant Industry. http://www.doacs.state.fl.us/pi/enpp/ento/ chillithrips.html (3 September 2009).

Holtz T. 2006. NPAG Report: Scirtothrips dorsalis Hood. New Pest Advisory Group, Center for Plant Health Science and Technology, APHIS, USDA, Raleigh, North Carolina. 7 pp.

Hoddle MS, Mound LA, Paris DL. (2009). Scirtothrips dorsalis. Thrips of California. http://keys.lucidcentral.org/keys/v3/ thrips_of_california/data/key/thysanoptera/Media/ Html/browse_species/Scirtothrips_dorsalis.htm (14 September 2009).

Klassen W, Seal DR, Ciomperlik MA, Fieselmann, DA. 2008. The chilli thrips, Scirtothrips dorsalis: current status in the Greater Caribbean Region. Proceedings of the Caribbean Food Crops Society 44: 103-117.

Kodomari S. 1978. Control of yellow tea thrips, Scirtothrips dorsalis Hood, in tea field at east region in Shizuoka prefecture. Journal of Tea Research 48: 46-51.

Ludwig S. (2009). Chilli thrips: a new pest in Texas. East Texas Nursery and Greenhouse IPM Program. http://chillithrips.tamu.edu/ (3 September 2009). 
Meissner H, Lemay A, Borchert D, Nietschke B, Neeley A, Magarey R, Ciomperlik M, Brodel C, Dobbs T. 2005. Evaluation of possible pathways of introduction for Scirtothrips dorsalis Hood (Thysanoptera: Thripidae) from the Caribbean into the continental United States. Center for Plant Health Science and Technology Plant Epidemiology and Risk Assessment Laboratory, Raleigh, NC.

Mound LA, Palmer JM. 1981. Identification, distribution and host plants of the pest species of Scirtothrips. (Thysanoptera: Thripidae). Bulletin of Entomological Research 71: 467-479.

Mound LA. (September 2007). Oriental tea thrips (Scirtothrips dorsalis). Pest and Diseases Image Library. http://www.padil.gov.au/ viewPestDiagnosticImages.aspx?id=241 (14 September 2009).

Osborne LS. (2009). Chilli Thrips, Scirtothrips dorsalis Hood.

http://mrec.ifas.ufl.edu/lso/thripslinks.htm (3 September 2009).

Rao RD, Prasada VJ, Reddy AS, Reddy SV, Thirumala-Devi K, Chander Rao S, Manoj Kumar V, Subramaniam K, Yellamanda Reddy T, Nigam SN, Reddy DVR. 2003. The host range of tobacco streak virus in India and transmission by thrips. Annals of Applied Biology 142: 365-368.

Ramakrishna Ayyar TV. 1932. Bionomics of some thrips injurious to cultivated plants in South India. Agriculture and Livestock of India 2: 391-403.

Ramakrishna Ayyar TV, Subbiah MS. 1935. The leafcurl disease of chillies caused by thrips in the Guntur and Madura tracks. The Madras Agricultural Journal 23: 403-410.

Sanap MM, Nawale RN. 1987. Chemical control of chilli thrips, Scirtothrips dorsalis. Vegetable Science 14: 195-199.

Seal DR, Ciomperlik M, Richards ML, Klassen W. 2006a. Comparative effectiveness of chemical insecticides against the chilli thrips, Scirtothrips dorsalis Hood (Thysanoptera: Thripidae), on pepper and their compatibility with natural enemies. Crop Protection 25: 949-955.

Seal DR, Ciomperlik M, Richards ML, Klassen W. 2006b. Distribution of the chilli thrips, Scirtothrips dorsalis Hood (Thysanoptera: Thripidae), within pepper plants and within pepper fields on St. Vincent. Florida Entomologist 89: 311-320.

Seal DR, Jha V, Klassen W, Sabine K. 2008. Response of chilli thrips, Scirtothrips dorsalis, and melon thrips, Thrips palmi, to some selected insecticides. Proceedings of the Caribbean Food Crops Society 44: 578.

Seal DR, Klassen W, Jha V. (2009a, in review). Biological parameters of chilli thrips, Scirtothrips dorsalis Hood, on selected hosts. Environmental Entomology.

Seal DR, Jha V. (2009b, in review). Biological response of chilli thrips, Scirtothrips dorsalis Hood (Thysanoptera: Thripidae), to various regimes of chemical and biorational insecticides. Crop Protection.

Skarlinski TL. 2004. Study to determine the efficacy of a shaker box for thrips sampling during inspections of peppers from St. Lucia and St. Vincent. May 12, 2004 - June 10, 2004. Report, July 1. USDA-APHIA-PPQ. Miami, FL.

Venette RC, Davis EE. 2004. Chilli thrips/yellow thrips, Scirtothrips dorsalis Hood (Thysanoptera: Thripidae). Mini Pest Risk Assessment. University of Minnesota, St. Paul, MN, USA. 31 pp. 